\title{
IDENTITY AS A CONSTRUCT: READING BLACKNESS IN EUGENE O'NEILL'S THE EMPEROR JONES
}

\author{
MARÍA ISABEL ROMERO-PÉREZ \\ Universidad de Granada \\ maribelromero@correo.ugr.es
}

Received 16 July 2020

Accepted 24 September 2021

\section{KEYWORDS}

The Emperor Jones; Eugene O’Neill; identity; hybridity; otherness; whiteness; blackness; primitivism.

\section{PALABRAS CLAVE}

El Emperador Jones; Eugene O'Neill; identidad; hibridismo; otredad; blanquitud; negritud; primitivismo.

\begin{abstract}
This paper aims to explore how racialized identities are typified as a modernist construct in Eugene O'Neill's The Emperor Jones (1920). To this end, the notion of whiteness is identified as a mediated construct and contextualized in the proliferation of American minstrel shows. This popular entertainment projected to white audiences the racial means of differentiation from black caricatures and clichés at the time of segregation. The echoes of minstrel shows and modernists' instrumentalization of 1920s primitivism serve to initially address the characterization of blackness in Brutus Jones' identity. Assessed through this in-between construction of symbolic borderlands in which the protagonist is both colonizer and colonized, his blackness becomes a metaphorical mask of otherness while his whiteness shapes the colonial performance of material whiteness. Although he envisions the white ideal in his systematic practices in the Caribbean island, his fragmented identity and his hybridity subject him to a primeval racialized past, to primitivism and atavism.
\end{abstract}

\section{RESUMEN}

Este artículo tiene como objetivo examinar la medida en que las identidades racializadas son tipificadas como un constructo modernista en El Emperador Jones (1920) de Eugene O'Neill. Para tal fin, la noción de blanquitud es identificada como un constructo mediado y contextualizado en la proliferación de los minstrel shows 
americanos. Esta forma de entretenimiento popular proyectó a las audiencias blancas los medios raciales de diferenciación frente a las caricaturas negras y clichés durante la segregación. Los ecos de los minstrel shows y la instrumentalización modernista del primitivismo de la década de 1920 sirven para inicialmente abordar la caracterización de la negritud en la identidad de Brutus Jones. Evaluado a través de esta construcción intermedia de los márgenes simbólicos en los que el protagonista es tanto, colonizador como colonizado, su negritud se convierte en una máscara metafórica de otredad mientras que su blanquitud moldea la interpretación colonial de la blanquitud material. Aunque él aspira al ideal blanco en sus prácticas sistemáticas en la isla caribeña, su identidad fragmentada e híbrida lo somete a un pasado primigenio $\mathrm{y}$ racializado, al primitivismo y atavismo.

\section{INTRODUCTION}

Eugene O'Neill's theater was influenced by modernists' search for aesthetics, innovation and experimentation, and by the tensions and ambivalences of dramatic literary modernism (Cunningham 12, 15; Ellmann and Feidelson vi). ${ }^{1}$ In 1920 he staged The Emperor Jones at the Broadway Theater as an expressionistic exploration of identity. For the first time in American history, a black actor was featured for a leading role in O'Neill's play, and on the Broadway stage. The dramatist's choice for Brutus Jones' role was Charles Gilpin, an actor who was familiarized with the acting in popular minstrel shows (Monroe 139). Gilpin's membership in The Provincetown Players came at the time when Jim Crow Laws legalized racial segregation. ${ }^{2}$ Before the 1920s, black actors almost exclusively participated in minstrelsy. These stereotyped shows drew on comedic distortions of African American culture and history to white audiences (Jouve 4; Bloomquist 412-414). The "representation of blackness" was also entrusted to "whites in blackface," although African Americans became part of minstrelsy entertainment in the 1840s (Monks 540).

\footnotetext{
${ }^{1}$ O'Neill's departure from sentimental melodrama and moralism in The Emperor Jones and The Touch of the Poet (1942) came to fashion the discourse of American modernity (Fiet, "O'Neill's Modification of Traditional American Themes" 514).

2 The era of Gilpin's success "was characterized by a serious revival of the Ku Klux Klan, rampant anti-black violence across the U.S., Jim Crowism, legislative efforts to negate the Constitutional rights of blacks, disfranchisement, and other forms of racial discrimination" (Monroe 141).
} 
This explains Gilpin's controversy with the Drama League. He was very conscious of the difficulties for African Americans in theater; however, this did not prevent him from receiving the recognition of the Drama League of New York for his performance as Brutus Jones. The success of The Emperor Jones on stage is well documented in modernist theater (Folino-White 98).

Critical accounts of O'Neill's work reaffirm its novelty, as well as the controversies in staging this play throughout decades. Harlem audiences urged Brutus Jones to come out of the fallacy of the African jungle and to go back to his original Harlem (Pfister 130). For Harlem audiences, Jones' depiction was a distorted reflection of blackness. In 1992, The Wooster Group staged their adaptation of O'Neill's play by exposing the characters' whiteness and deconstructing their identities as fictional constructs (Jouve 14). The portrayal of Jones' otherness and identity in the context of modernism has been mainly approached from the field of psychoanalysis, which combines the relationship between trauma and expressionism with Freudian and Jungian views of the unconscious and Nietzschean aesthetics (Nethercot 2013; Wenquian Zhang 2014). A major limitation of this approach to the study of the collective unconscious is that it "cannot entirely account for the centrality of race in the play," or account for the fact that "what is really lacking is a justification of the tribe's ancestral past being meaningful" to the individual experience of Jones (Nolan §3). ${ }^{3}$ The dissolution of his colonized identity in a "symbolic oneness" reshapes his identity as a silent referent from an "absent origin that is never a presence" (Steen 607, 610). In other words, the protagonist's blackness is an artificial one, a symbol of otherness. As a fictional construct, the social alienation of the Other is possibly an echo of O'Neill's own identity. The ultimate collective trauma is shared by Jones and the natives of the island. The exotic and primitive setting of the play is a reminder of the racial anxieties held by white audiences (Smith 2009) and their "yearning for historical amnesia" (Beyad and Roshnavand 32). O'Neill's play has come to dramatically represent "what white society has done to black culture" in "his personification of African-American [recorded] history" (Diggins 147).

This brief introduction to the critical accounts of The Emperor Jones, and of Charles Gilpin as its leading actor serve to

\footnotetext{
${ }^{3}$ For further reference to online literature without page numbers, the following symbol " $\beta$ " is used to indicate the numbered paragraphs in which citations can be located.
} 
contextualize the dramatic use of racialized identity as a construct in O'Neill's play. Primarily influenced by the primitivistic vogue of the 1920s, modernists' experimentation and aestheticized ethnicities shape the identity of its protagonist, namely, Brutus Jones, as a construct, an identity that is in the process of differentiation. In order to explore the portrayal of whiteness and blackness in Brutus Jones, this paper is organized as follows. Firstly, an overview of the minstrel shows in the American theater is given in relation to Jones' characterization. Secondly, the notion of blackness is presented as a construct based on modernists' fascination with the African continent, and furthermore, delineated on the physical and metaphorical borders of both difference and belonging. Thirdly, Jones' resourceful blackness is metaphorically regarded as a representation of O'Neill's otherness as an Irish-American. To the understanding of these complex processes of embodiment and disembodiment, fourthly, the journey trope is discussed as a cluster of narratives that problematize Jones' fragmented identity. Additionally, his hybridity is juxtaposed to his strategic control of the truth in the Caribbean while he maintains his dominion over the colonial enterprise. Outlined as a construct, the Emperor's hybrid and irreconcilable identity verifies the permeability of colonial whiteness and of atavism in The Emperor Jones.

\section{WHITENESS AS A CONSTRUCT: THE MINSTREL SHOWS IN AMERICAN THEATER}

The construction of African American identities in modernist theater was grounded in American minstrel shows of the nineteenth and twentieth centuries. Minstrelsy entertainment in America gave evidence of the fascination of national audiences with black culture since the late 1820s, at the same time that it had served as a justification for slavery before the Emancipation Proclamation (Bloomquist 411). Blackface comedies in the minstrel shows had let white audiences watch from a safe distance their own "fascination with blackness" (Ellison 79). Complex feelings and attitudes towards African Americans emerged from minstrelsy, which produced stereotyped images of both blackness and whiteness (Monks 544). ${ }^{4}$

\footnotetext{
${ }^{4}$ Blackness was produced "through the grotesque caricatures in the images created by the minstrel stage, which subsequently mediated how black people themselves were
} 
These shows, according to William J. Mahar (242) and Jacob Levine (13), performed a social function that allowed audiences to experiment a symbolic release of aggressiveness. Black caricatures from the minstrel shows reflected the effect of stereotyping originated from the plantation myth on the racial anxieties of Americans (Saxton 8).

Status-reversal comedies and minstrel shows reproduced comic characteristics in the construction of black characters. Characters usually in blackface were sometimes presented in positions of power and were allowed temporarily to dominate other characters, although they could not sustain their authority for long. As in the case of Brutus Jones, they were not entitled to possess power (Mahar 259). Jones occupies an intermediate position in the social structure of the Caribbean that not only stems from minstrelsy echoes, but also amplifies the abilities of his characterization to intervene in more than brief occasions or, "in farcical situations" (Mahar 259). Audiences understood O'Neill's Jones as a "construction mediated through minstrelsy" (Monks 555). But the play, as All God's Chillun Got Wings (1924), also legitimized the leading presence of black actors on stage, and, therefore "invited [audiences used to minstrelsy] to reevaluate their former perceptions of blackness and of the black character" (Le Bastard §1). However, the modernist exploration of Jones' African American identity was primarily shaped by modernists' celebration of the primitivist vogue of the 1920s and the Harlem Renaissance.

\section{BLACKNESS AS A CONSTRUCT}

Brutus Jones' portrait is constructed through O'Neill's oneact and eight-scene expressionist play. His non-fixed identity is one of the images of the "primitive, exotic and hedonistic black" of modernist literature (Beyad and Roshnavand 19). His blackness is "fit to galvanize a moribund civilization", in post-war America (Feuser 291). Modernists' search for innovation and their disillusionment with Western civilization led artists to explore other alternative cultures. The 1920s of modernism and of the Lost Generation were symbolically referred to as the Jazz Age, the era that witnessed the emergence of primitivism, the West's "remedy for its sterility and

seen, and whiteness through the homogenizing effects of the burnt cork mask" (Monks 544). 
bleakness," the "hedonism and exoticism" during the interwar period (Roshnavand 38,41 ). Brought on by cubist painters and the avantgardists in general, and the rediscovery of African paintings, the primitive vogue became a decade that brought attention on Africa as a paradigm of primitive life, the "notorious and frightening Dark Continent" (Beyad and Roshnavand 23). This "shapeless and demonic" continent eventually represented the trope of the primitive unconscious and the jungle as a reservoir of universal fear as in Joseph Conrad's Heart of Darkness (1902) (Saiz 32). Through modernists' exploration, the primitive other was constructed as a mirroring site to escape history and to reiterate the nostalgia for the past.

Even though Charles Gilpin performed the leading role in The Emperor Jones, modernist primitivism problematizes Jones' blackness. Jones is introduced as a hybridized character from the moment he enters the stage. His liminal identity enforces a "racial masquerade" of whiteness, which is mediated by the "vogue of racial ventriloquism" in O'Neill's creation and in Gilpin's acting (Beyad and Roshnavand 28). ${ }^{5}$ The notorious and irreconcilable description of his clothing and appearance foreshadows the tragedy.

JONES enters from the right. He is a tall, powerfully-built, fullblooded Negro of middle age. His features are typically negroid, yet there is something decidedly distinctive about his face-an underlying strength of will, a hardy, self-reliant confidence in himself that inspires respect. His eyes are alive with a keen, cunning intelligence. In manner he is shrewd, suspicious, evasive. He wears a light blue uniform coat, sprayed with brass buttons, heavy gold chevrons on his shoulders, gold braid on the collar, cuffs, etc. His pants are bright red with a light blue stripe down the side. Patentleather laced boots with brass spurs, and a belt with a long-barreled, pearlhandled revolver in a holster complete his make up. Yet there is something not altogether ridiculous about his grandeur. He has a way of carrying it off (O'Neill 269).

Jones is initially characterized as an intruder, a man out of his element. He displays a proud countenance and wears elegant clothes, but he is carrying out a performance. In fact, the 1920 production was designed to expose the fetishizing effect of Gilpin's

\footnotetext{
5 The racial construction of O'Neill's character was renegotiated by Gilpin, who rejected the repetitive use of the word nigger in the screenplay (Krasner 190).
} 
skin in contrast with the white cyclorama (Steen 348). Jones' identity is strategically positioned between the masters' dialectics of whiteness and the indigenous peoples' blackness. Jones the emperor was Jones the Pullman porter and former racialized slave.

Nevertheless, like secondary characters who finally outwit their antagonists, Brutus Jones is willing to control the colonized, enslaved and oppressed peoples. One of his strategies is to take advantage of the masters' language by putting into practice the knowledge he has gathered in ages of servitude: "If dey's one thing I learns in ten years on de Pullman ca's listenin' to de white quality talk, it's dat same fact. And when I gits a chance to use it I winds up Emperor in two years" (O'Neill 271). The rhetoric of whiteness enables Jones to seize power by alienating the natives' lexicon as inferior. Life experience has taught Jones to gain leverage in the mechanisms of colonization, which are precisely the same strategies that had been tyrannically caricaturizing his whiteness. As in Shakespeare's The Tempest, language becomes a prominent force between civilization and primitivism. Jones' words echo Caliban's speech when he says to Miranda and Prospero, "You taught me language, and my profit on't / Is I know how to curse. The red plague rid you / For learning me your language!" (1.2. 362-4). By the same token, Jones sees the profit in cursing, in other words, in using the masters' language to access the masters' privileges. But Jones' English is "distinctive for its rolling patois" (Steen 347). Jones shares partial features of both Prospero and Caliban, the domineering and the dominated. Indeed, "Jones has been intellectually colonized" (Mendelssohn 20). His bilingualism confirms his desire for whiteness, while it coerces him into bearing a volatile double self (Mendelssohn 22). His "identity talk" is directed to what he envisions as his identity, a collective identity that is shared by the masters of colonial rule (Rohlinger, et al. 180). Additionally, this racial ventriloquism conceived by language presents a clash between the influence of standardized linguistics and the freedom of non-standardized dialects that were being used after the advent of the primitivist vogue in the United States (Beyad and Roshnavand 29; North 26).

Dialect literature and comedy, such as minstrel shows, became popular in the Abolition Movement, the Emancipation, the Reconstruction and the Jim Crow period. Black culture and language have been the object of modernists' fascination and a valid source of exploitation for entertainment (Bloomquist 422). As an aftermath of the American Civil War, and the later Reconstruction, O'Neill's drama 
results in a culturally unified white-American narrative. The Emperor Jones is part of an era in which social, cultural and political distress guaranteed audiences the continuation of widespread stereotypes of black American peoples. In Smith's words (61), America still held a national trauma that "sought to erase painful divisive memories and construct a conciliatory nationalist narrative," even at the expense of racialized de-colonization at the end of the Civil War and the beginning of the First World War. The collective memories of American whiteness created the symbolic borders that "delineate systems of difference and belonging" (Mendez and Naples 2). Based on systematic difference, the press refined and distributed part of the large propagandistic agenda that was dealing with racial issues. The struggle between white and black cultures at the time O'Neill's play was acted coalesces around the dialogue of border politics, the "figurative borders of inclusion and exclusion" during segregation; they are border politics that "destabilize constructions of agency and belonging as linked to formal legal categories of political membership" (Mendez and Naples 2). In this light, O'Neill's Jones is metaphorically transformed into a source of historical politics, identities and cultural memories. He has to embody part of the "American allegory" and, by extension, of the "traumatized American" individual (Smith 62). ${ }^{6}$

Regarding the cultural meanings and identities demarcated by border politics, Jones' fictional figure acquires the stereotyped clichés and caricature of the borderlands. ${ }^{7}$ As African American, his identity is characterized by "in-betweenness" (Mendez and Naples 3), by the "open wound" of "the lifeblood of two worlds merging to form a third country-a border culture," a border identity (Anzaldúa 2, 3). This political conflict alienates Jones' storyline by forcing him to lurk in the discourse of trauma. As a result, his in-betweenness additionally draws on the ambiguous relocation and

\footnotetext{
${ }^{6}$ Smith spots (62-64) three popular examples relevant to the background of O'Neill's The Emperor Jones. Firstly, the 1834 song "Zip Coon," secondly, George Kibble Turner's short story "The Cannibal King" (1910), and thirdly, Thomas Dixon's play The Clansman (1905), based on D.W. Griffith's film The Birth of a Nation (1915) - which was "instrumental in creating the mythology and ideology of the Ku Klux Klan (KKK)"

7 John R. Cooley (76) elaborates on the relationship between the Harlem Renaissance and Brutus Jones' stereotypes on stage performance as an antagonist element, which was part of "O'Neill's racial ambivalence" in criticising and perpetuating at the same time racial generalisations.
} 
reconceptualization led by modernists' representations. By seizing systematic structures of colonial power, he introduces "the destruction of a 'white' [racial] Utopia," while his black identity disturbs "the master narrative of 'naturalized' racism and national amnesia" (Smith 64, 66). Jones' identity is presented as being in the process, that is, under construction. When his collective identity manifests itself in the form of atavism, ${ }^{8}$ Jones turns into a commodity, a mere tradeable body in a fictionalized landscape set after the Civil War and the Thirteenth Amendment in 1865, yet contextualized far from the abolition of slavery. The unsettling colonial past extracts the genealogy of oppression fragmentarily. The trespassing of these boundaries, both geographic and metaphorical, disarticulates the wholeness of the group identity and of its racialized collective memory (Rohlinger, et al. 177; Taylor and Whittier 176). Nevertheless, by presenting him as standing on a tree stump, Jones is exposed to the dynamics of the boundaries he attempted to escape. In the fifth scene, the protagonist is sold to a slave owner and the highest bidder. He is therefore commodified, subjected to the laws of the colonial market: "Is dis a auction? Is you sellin' me like dey uster befo' de war? [...] And you sells me? And you buys me? I shows you I'se a free nigger, damn yo' souls!" (O'Neill 286). In the context of pre-abolitionist America, he is perceived as raw material, a work tool for slave traders and plantation owners.

At the crossroads of freedom and captivity, the Emperor tracks the footsteps of his own double self and distorted identity. His final return to the West Indies, to "the diaspora of Africa", conveniently reveals the "cultural estrangement" held by modernists (Saiz 32). Their views on characters such as Jones, or the cockney trader Smithers show the unsolved historical tensions of Reconstruction. Alienated and an outsider, Jones is depicted as a free citizen, yet, still as "a bewildered, frightened Negro," a victim of his lifetime, "of his past, both racial and personal" (Whitman 148). To some extent, he has to renegotiate the boundaries of his identity. He is exposed to the idea of materialism, and sees a common aim to both races, black and white, in Patrick J. Nolan's words, "a participation in power and harmony with the laws of the universe"

8 Cooley (78) defines atavism in relation to collective cultural identity, as stemming from two premises, "that some individuals exhibit traits and characters of ancestors, absent in intervening generations, and that individuals occasionally revert to the features and life styles of their ancestors." 
(§13). Jones appropriates the colonizing rhetoric of the oppressor by centralizing the power of a Caribbean island, and of its native peoples.

\section{BLACKNESS AS A METAPHOR OF O'NEILL'S IRISHNESS}

Son of an Irish immigrant and actor, the Irish-American Eugene O'Neill himself represents an image of otherness that permeates his theatrical characters and texts. O'Neill's sympathy for the Other and his fascination with primitivism relate to characters who "disavow their own community and fail to join another," as it is the case with Brutus Jones (Le Bastard §32). He cannot disengage himself from the cultural baggage he carries, which includes the collective memories of British colonialism and the stigmatized categorization of Irishness as a synonym of barbarism and blackness. ${ }^{9}$ Criminal activity was commonly treated as an "ethnic succession" that began with the "intemperate disposition of the Irish race" in the 1860s and continued with the association of African Americans with violence (Steinberg 117-118). When Irish immigrants were introduced to minstrelsy, stereotyping was applied to them, and thus, Irish blackface came to exemplify racial duplicity (Mahar 245, 251). ${ }^{10}$ The blackened faces of these Irish performers created a paradoxical effect that had been initiated in Charles Darwin's The Origin of Species (1859) (Curtis 29-114). Rapid growth of immigration to the United States translated into satirized descriptions of the Irish in both Britain and the States. Alienating images pictured Irish identity as stigmatized, dehumanized, and ultimately animalized, ape-like. Propaganda joined together Irishness with an emphatic portrayal of inferiority. ${ }^{11}$ Irish physiognomy-of darkened and simianized peoples-was targeted for hyperbole, caricature and distortion. Despite the fact that phrenology was discredited as a

\footnotetext{
9 O'Neill's entangled relation with otherness, despite his American born origin, can establish a dialogue between nostalgia, historicity and biography-crossing the borders of the States-in contemporary chronicles at the time in Ireland: covering the Easter Rising and the Irish War of Independence.

${ }^{10}$ According to Aoife Monks (545), Irish participation in minstrel shows exacerbated the stigmatized caricatures of blackness by means of racial differentiation.

11 Irish otherness and the Celtic Revival have been major topics in contemporary literature of British Colonial rule, in which Elizabeth Cullingford's (99-131) tropes of Romans and Carthaginians parallel the British and the Irish arenas.
} 
scientific theory, "cranial measurement [was used] as an indicator of intelligence" (Mahar 268). The 1910s, 1920s and 1930s propaganda definitively had an impact on the understanding and misconception of race and ethnicity.

Assessed through the discourse of melancholic embodiment, O'Neill's The Emperor Jones locates both Irish and African American narratives at a problematic meeting point. They are displaced from a common homogeneous past. Jones is "unhomed" because he cannot identify neither with an African self, or with an American one, he is lost in an "oxymoronic African-American identity" that leaves him as "literally homeless" (Mendelssohn 26). Within global modernity, and in an intermediate racialized position, he cannot identify with a country, nor can he settle in the island for long. ${ }^{12}$ In Jones' narrative, “O'Neill maps onto a black body desperately trying to flee the phantoms of its personal and racial past," and furthermore, stresses his mapping ambiguously in an already "socially marginalized figure" (Steen 342, 352). Similarly, Jones belongs to this ambivalent semiotic of whiteness in which he is "both white (in relation to nonEuropean peoples) and black (in relation to the British AngloAmericans" (Steen 352). Like his main character, O'Neill ultimately draws on the tragic mulatto motif. His cultural identity may have enabled him to embrace a dual view of Jones' blackness at a time when Social Darwinism was prevalent. It reconnects the idea of the survival of the fittest with the belief that affective relationships with "dark peoples compromised white selfhood and threatened race purity" (Boehmer 65).

The historically alienated position of black and Irish peoples must have influenced the construction of O'Neill's characters. And in the dual alienation of O'Neill, the collective memories of migration may be exposed in Jones' blackness. Jones' tragedy is framed in the liminal and marginalized status of Irish and black peoples (Steen 356). Certainly, there is an interplay between the "primitive African mask," that shows blackness through "a white prism," and "the white mask, which is forced upon black men in a still segregated society" (Le Bastard §26). Brutus Jones is too black to escape his past as a Pullman porter, though he is not white enough to trespass the boundaries of colonial rule and colonial ambition at the same time that O'Neill's melancholic embodiment becomes "a projection of

12 Vandana Shiva (98) points to "homelessness [as] a cultural characteristic of the late twentieth century," which originated in the colonial and capitalist enterprise. 
the white O'Neill in racial drag, a fantasy of both his blackness and his own whiteness" (Steen 353). ${ }^{13}$

\section{THE JOURNEY TROPE AND JONES' HYBRIDIZED IDENTITY}

Brutus Jones the Pullman porter is transformed into emperor, commodified as merchandise, treated as an employee, and regarded as a slave at different points in time. He is repeatedly at a crossroads of spatio-temporal clustering and the geographical borders that deconstruct Jones' discourse. He is at the crossroads of his individual migratory movement and the collective displacement of former plantation slaves from the Caribbean to New Orleans (Otero Garabís 970, Benítez Rojo 115-130). Initially, Jones was granted manual labor, "dirty work," but also, he is asked to do "brain work" based on calculation and mediation (O'Neill 270). He is able to perform both of these tasks, and in order to fulfill his desire for white embodiment, he devotes himself to the Caribbean performance by wearing the colonial mask of whiteness and therefore, by placing out of view the narratives of the natives of the island (Benitez Rojo 127). By performing the role of a colonial authority, his identity and sense of belonging disintegrate in a nation-state community that cannot validate his masquerade. The city of New York and the idealized nation that he sees as paradigms of safety, were still governed by racial segregation. If there is any possibility that he reconstructs his nation-based identity, it its annihilated as he becomes vulnerable to the effects of homelessness (Edwards and Graulund 7).

The protagonist's journey is circular and symbolic. His circular movement through the island echoes forced migratory movements and matches the sailor motif while he is moving "to and fro between nations," across continental borders in "micro-systems of linguistic and political hybridity" (Gilroy 12). When Jones arrives for the first time at the Caribbean, he immediately envisions his expedition into the hinterland as an opportunity. By making profit of the natural resources of the island's ecosystem, such as its soil, minerals or vegetation he draws the labyrinth of the colonial enterprise. Since the 1500 s to nearly the 1700 s, the Caribbean was chosen as one of the golden areas of commercial interest, in which

\footnotetext{
${ }^{13}$ It is "the ghosts of the artist's mind, so insistently real that they threaten to enter the corporeal world, [and] are banished finally into the plane of representation," into O’Neill's text (Dawes 59).
} 
colonialism appropriated lands and peoples worldwide by means of military fleets, armament and scientific theories (Hulme and Youngs $124,258)$. In this scenario, Jones' aims to seize colonial power are in reality an irreconcilable performance. His "journey-to-thecrossroads" ends dramatically as he is forced to move in circles, "from clearing to forest clearing until he reaches the Africa conjured by the hallucinatory state produced by his fear, anguish, and guilt" (Fiet, "Walcott's Way" 104, 105). And thus, the final descent into the dark jungle instills the collective sense of strangeness, death, danger and disenchantment in the story.

O'Neill's opening stage directions outline an ominously striking official residence. Jones' imperial throne is not lavishly ornamented, yet its flashy red predictably must call the attention of the audience:

The room is bare of furniture with the exception of one huge chair made of uncut wood which stands at center, its back to rear. This is very apparently the Emperor's throne. It is painted a dazzling, eyesmiting scarlet. There is a brilliant orange cushion on the seat and another smaller one is placed on the floor to serve as a footstool. Strips of matting, dyed scarlet, lead from the foot of the throne to the two entrances (O’Neill 267).

The palace of the Emperor Jones is almost unfurnished, with the exception of its wooden throne. The singularity of the emperor's chair adds to the "dazzling, eye-smiting scarlet" of the scene and to the white of the walls and floor (O'Neill 267). Scarlet and white tinged, this place draws on the colonial imaginary of the audience by showing the link between the color of blood and the racial whiteness of the colonial enterprise. The old woman who enters stage, the matting and cushions of the room reinforce the references to servitude. Here, Jones is presented as white and powerful as the representatives of colonial rule. His rule "in a forest setting manifests the first, necessary step in creating civilization, and by extension, his whiteness" (Folino-White 105). Though soon his emperor role is revealed to be a mask, there is something that belongs to his own identity, "yet there is something not altogether ridiculous about his grandeur. He has a way of carrying it off' (O'Neill 269). His emperor clothes loosely fit him, but he can easily accommodate to them. For Shannon Steen (347), he is the wealthy man whose clothes "signify power, but in a grotesque parody of that sign." He is described in a 
clothing metaphor that resembles the loose robes of the corrupt king in Shakespeare's Macbeth: "Now does he feel his title / hang loose about him, like a giant's robe / Upon a dwarfish thief" (V, ii, 20-22). It is the colonial performance of Jones that paradoxically strips him of his imperial clothes, his privileges and his title. And as a result, he is ultimately abandoned to the policies of the borderland, of exclusion from the social structures that demarcate whiteness, and of inclusion of the defining atavism of blackness. His identity is being constructed through social and symbolic "border politics as struggles that challenge, transcend, or reinforce" geographical borders (Mendez and Naples 4).

Nevertheless, profit maximization is the prime goal of masters in modernity, and Jones is aware of the social structure of capitalism. ${ }^{14}$ Indeed, "the capitalist appeal mesmerizes with its power and its prospect of self-sufficiency" (Nolan §14). Jones is mesmerized by money-making; he becomes part of the modern materialist ideal. Most likely, he travelled as a stowaway to the Caribbean, and, in order to make his fortune, he started working in Smithers' business and ended up establishing himself as emperor of the island. As emperor, he is in possession of the natives' riches, and of money, which "is the ultimate power that sinews the earth; its possession makes one master of life and, therefore, master over fear" (Nolan §9). In order to keep this ultimate capitalist power, he has planned to sail to Martinique, where he can transfer all his money to a bank account without paying taxes: "Dawn tomorrow I'll be out at de oder side and on de coast whar dat French gunboat is stayin'. She picks me up, take me to Martinique when she go dar, and dere I is safe wid a mighty big bankroll in my jeans" (O'Neill 275). His planned journey invokes a "central organising symbol," "a living, micro-cultural, micro-political system in motion" (Gilroy 4). The sailing motif is ostensibly tied to the borderland rhetoric that links together cultural and historical meanings. However, the ship metaphor conveys the idea that the homeland has a redeeming potential for Jones' crimes at the end, whereas in the beginning, it is a device that facilitates the flow of transcontinental ideas (Gilroy 4). But Jones's movements are erratic and as for other representatives of the "so-called Western

\footnotetext{
14 In O'Neill's explanatory notes of "Billionaire (1927)," he juxtaposes Brutus Jones' financial interest and obsessions in letting "his accumulated gold" possess him by taking hold of his own being (Floyd 168).
} 
civilization," his "crime is whiteness" (Fiet, "Walcott's Way" 109). His sentence is atavism, he is driven to the past as

two rows of seated figures can be seen behind JONES. They are sitting in crumpled, despairing attitudes, hunched, facing one another with their backs touching the forest walls as if they were shackled to them. All are negroes, naked save for loin cloths. At first they are silent and motionless. Then they begin to sway slowly forward toward each and back again in unison, as if they were laxly letting themselves follow the long roll of a ship at sea (O’Neill 287).

Jones' constructed identity has fragmented into pieces and his hybridized self has been lost in retrospect. He is pictured in relation to the primitive-nature relational pair, and represented in the logic of the discourse of colonization. The initial distance between the beliefs and motivations of Jones and the identities and culture of the natives is no longer necessary when his dictatorship ends (Steen 351). To a certain extent, the proximity of Jones' identification with a racialized conception of the Caribbean natives and with Africa gives audiences the image of the needed "Other," the "uncivilized," the cliché of the "tom-tom still in their blood and an indelible happy-golucky spirit in their hearts" (Roshnavand 41). In embracing his new identity, Jones feels a mystifying sense of familiar primitivism and of self-recognition when he sees a series of symbolic natural elements. He seems to know where he is standing: "What is"-dis place? Seems like-seems like I know dat tree-an' de river. I remember-seems like I been heah befo"' (O’Neill 288). To all intents and purposes, Jones crosses the forest as the ethnographer, by trespassing temporal boundaries and by framing the image of natives as ancient specimens "frozen in time" (Hulme and Youngs 134). His journey is "a journey through history," through his common past as a masquerade performer and bearer of whiteness (Monks 547). For Jones, the Caribbean is incorporated into the territorial crossroads of his homeland and the hinterland, both port, residence and landscape (Otero Garabis 970).

\section{HYBRIDITY AND THE CONTROL OF TRUTH}

The Emperor's rule over the Caribbean seas requires him to take control of the production of truth. By creating an alternative truth, he becomes a mythical presence, the white god that is both 
feared and venerated. He boasts of being almost immortal, a man who can only be neutralized by a magic silver bullet: "You said yer'd got a charm so's no lead bullet'd kill yer. You was so strong only a silver bullet could kill yer, you told 'em. Blimey, wasn't that swank for yer-and plain fat-'eaded luck?" (O'Neill 271). ${ }^{15}$ Like a reference to lycanthropy and shamanism, the silver bullet will eventually prove to be his ultimate weakness against the shadows of the phantasmagoria that keeps tormenting his consciousness. The natives' superstitions subordinate Jones to primitive nature, and, therefore, "the black man becomes dependent upon the vagaries of nature" (Nolan \$11). This association with the uncivilized and untamed unconscious reinforces the symbols of colonialism. As a byproduct of the ideal of a white Utopia, Jones' exploitative regime is characterized by "all vestiges of criminal purpose," the slave trade, penal labor and the use of weapons (Nolan §16). During his reverse journey, his dictatorship leads to his own fatal death, to the "astheticization and worship of violence and death" (Feuser 298).

Finally, the natives' rebellious counter-reaction destabilizes the complex hybrid identity of Jones, his acquired social status, and his superiority. With their ominous throb sound, the natives guide the steps of Jones through the forest at 3:30 in the afternoon. He has to venture through the impenetrable vegetation where he gradually loses the control of truth. As Michael Hardt and Antonio Negri claim (156), "truth will not make us free, but taking control of the production of truth will. Mobility and hybridity are not liberatory, but taking control of the production of mobility and stasis, purities and mixtures is." At this point, Jones' control of the truth, of what he sees and believes is in the hands of the natives. The natives' truth and Jones' previous past are now Jones' truth. By reclaiming and taking control of this production from Jones, the natives will turn ritual and magic into life and history. However, there is no certainty that another colonial representative will not aspire to the dominion over the Caribbean lands, peoples and resources when Jones is absent. 16

\footnotetext{
15 Cooley (75) confirms the origin of O'Neill's idea of the silver bullet from "a black circus employee. He told O'Neill the story of Vilbrun Guillaume Sam, who became dictator of Haiti and held onto his position for about six months."

16 As Hardt and Negri ask themselves: "What if a new paradigm of power, a postmodern sovereignty, has come to replace the modern paradigm and rule through differential hierarchies of the hybrid and fragmentary subjectivities [...]?" (138).
} 
Economic interest lies at the heart of the Emperor's colonial enterprise. He is not exclusively trading material goods or a façade, but he is also exporting colonial legacies of knowledge by means of imitation and epistemic friction. He is conveniently integrating his hybridized identity into the master's logic; he is not "holdin' down dis Emperor job for de glory in it," he openly declares that "Dey wants de big circus show for deir money. I gives it to 'em an' I gits de money" (O'Neill 270). He is acknowledging the performativity of whiteness to instrumentalize the Other. Willing to interpret his layered role, his hybridity assists him in seeing the various angles of colonialism. O'Neill's modernist drama articulates a critique of the racialized constructs of identity, and of the exploitation of colonial whiteness in the control and appropriation of the truth in The Emperor Jones.

\section{CONCLUSION}

O'Neill's The Emperor Jones presents a complex character whose operating identity has served to analyze the complexities of colonialism. Whiteness and blackness are introduced as constructs of the 1920s modernist fascination with primitivism, a symbol "cherished by Bohemian white intellectuals both in Europe and the U.S.A" (Feuser 294). Primitivism is part of the characterization of the protagonist, who manages to ascend the imperial throne, but who is also led to the fragmentation of his identity. His self in the process of construction explores how slavery, segregation and racialized amnesia have an effect on the representation of black Americans. His hybrid self cannot be reconciled with the whiteness he desires to attain. Jones is at the crossroads of individual and collective identities, and of the cultural meanings embedded in his atavistic return to Africa.

Subservient to the discourse of trauma and otherness, Brutus Jones encounters both the archetypes and stereotypes of Irishness and blackness. The racial construction of O'Neill's character points to his own Irishness as a symbolic literary black mask of identification (Steen 351-352). This cultural exploration came at a time when Celtic ancestry was depicted as blackness (Steen 352). Even though O'Neill's main character initially succeeds in his performance of whiteness, his oxymoronic self-positioning as 
emperor cannot maintain his social position for a considerable time. By partaking in the cultural reproduction of sameness and difference, his hybridity places Jones closer to nature, anchored in a collective past which is mythical and primitive. Nevertheless, his strategic use of the masters' language in the West Indies and, ultimately, of his money would not grant him the control of the production of truth indefinitely.

\section{WORKS CITED}

ANZALDÚA, Gloria. Borderlands/La Frontera. Aunt Lute Books, 1987.

BENÍTEZ ROJO, Antonio. "La Isla que se Repite: Para una Reinterpretación de la Cultura Caribeña." Cuadernos Hispanoamericanos, no. 429, March, 1986, pp. 115-130.

BEYAD, Maryam and Farshad Roshnavand. "The Instrumentality of the Black 'Other' in Primitivist Modernism: A Critical Analysis of Modern Dance and Modernits Language." Legon Journal of the Humanities, vol. 24, 2013, pp. 19-36.

BLOOMQUIST, Jennifer. "The Minstrel Legacy: African American English and the Historical Construction of 'Black' Identities in Entertainment." Journal of African American Studies, vol. 19, 2015, pp. 410-425.

BOEHMER, Elleke. Colonialism and Postcolonialism: Migrant Metaphors. Oxford UP, 2005.

COOLEY, John R. "The Emperor Jones and the Harlem Renaissance." Studies in the Literary Imagination, vol. 7, no. 2, 1974, pp. 73-83.

CULLINGFORD, Elizabeth Butler. Ireland's Others: Gender and Ethnicity in Irish Literature and Popular Culture. Cork UP, 2001.

CUNNINGHAM, Frank R. "O'Neill's Beginnings and the Birth of Modernism in American Drama." The Eugene O'Neill Review, vol. 17, no. 1/2, Spring/Fall, 1993, pp. 11-20.

CURTIS, Perry Jr. L. Apes and Angels: The Irishman in Victorian Caricature. Smithsonian, 1997. 
DAWES, James R. "Drama and Ethics, Grief and Privacy: The Case of Eugene O'Neill." The Eugene O'Neill Review, vol. 17, no. 1/2, Spring/Fall, 1993, pp. 82-92.

DIGGINS, John Patrick. Eugene O'Neill's America: Desire under democracy. The U of Chicago P, 2007.

EDWARDS, Justin D. and Rune Graulund, editors. Postcolonial Travel Writing: Critical Explorations. Palgrave Macmillan, 2011.

ELLISON, Ralph. Shadow and Act. Random House, 1964.

ELLMANN, Richard and Charles Feidelson, Jr., editors. The Modern Tradition: Backgrounds of Modern Literature. Oxford UP, 1965.

FEUSER, Willfried. "Black Reflections in a White Mirror. Literature and Culture in the "Twenties." Neohelicon, vol. 20, no. 1, 1993, pp. 289306.

FIET, Lowell A. “O'Neill's Modification of Traditional American Themes in 'A Touch of the Poet'." Educational Theatre Journal, vol. 27, no. 4, December, 1975, pp. 508-515.

---. 'Walcott's Way: 'Do you know where you are?' 'At Crossroads in the Moonlight'." Sargasso, 1999, 103-113.

FLOYD, Virginia, editor. Eugene O'Neill at Work: Newly Released Ideas for Plays. Frederick Ungar, 1981.

FOLINO-WHITE, Ann. "In the Service of Man: Women and Male Racial Mobility in The Emperor Jones." American Drama, vol. 13, no. 2, 2004, pp. 98-117.

GILROY, Paul. The Black Atlantic: Modernity and Double-Consciousness. Verso, 1993.

HARDT, Michael and Antonio Negri. Empire. Harvard UP, 2000.

HULME, Peter and Tim Youngs, editors. The Cambridge Companion to Travel Writing. Cambridge UP, 2013.

JOUVE, Emeline. "Gender and Race Trouble: The Emperor Jones by The Wooster Group.” Angles, vol. 1, 2021, pp. 1-19. 
KRASNER, David. A Beautiful Pageant: African American Theatre, Drama, and Performance in the Harlem Renaissance, 1910-1927. Palgrave Macmillan, 2002.

LE BASTARD, Gwenola. "Censorship, Control and Resistance in Eugene O'Neill's 'black plays' The Emperor Jones and All God's Chillun Got Wings." Revue LISA/LISA e-journal, vol. 11, n. 3, November, 2013, https://journals.openedition.org/lisa/5519. Accessed 24 May 2021.

LEVINE, Jacob. "Aproaches to Humor Appreciation." Motivation in Humor, edited by Jacob Levine, Atherton Press, 1969, pp. 1-28.

MAHAR, William J. "Ethiopian Skits and Sketches: Contents and Contexts of Blackface Minstrelsy, 1840-1890.” Prospects, vol. 16, 2009, pp. 241279.

MENDELSSOHN, Michèle. "Race, Language and Identity in 'The Emperor Jones'." The Eugene O'Neill Review, vol. 23, no. 1/2, Spring/Fall, 1999, pp. 19-30.

MENDEZ, Jennifer Bickham and Nancy A. Naples. "Border Politics: Contests over Territory, Nation, Identity, and Belonging." Border Politics: Social Movements, Collective Identities, and Globalization, edited by Nancy A. Naples and Jennifer Bickham Mendez, New York UP, 2015, pp. 132.

MONKS, Aoife. “'Genuine Negroes and Real Bloodhounds': Cross-Dressing, Eugene O'Neill, the Wooster Group, and The Emperor Jones." Modern Drama, vol. 48, no. 3, Fall, 2005, pp. 540-564.

MONROE, John G. "Charles Gilpin and the Drama League Controversy." Black American Literature Forum, vol. 16, no. 4, Winter, Black Theatre Issue, 1982, pp. 139-141.

NETHERCOT, Arthur. "The Psychoanalyzing of Eugene O'Neill." Modern Drama, U of Toronto P, vol. 3, no. 4, 1960, pp. 357-372.

NOLAN, Patrick J. "The Emperor Jones: A Jungian View of the Origin of Fear in the Black Race." The Eugene O'Neill Newsletter, vol. 4, nos. 1-2, May-September, 1980, https://wayback.archiveit.org/11063/20190124162305/http:/ / eoneill.com/library/newslett er/iv_1-2/iv-1-2c.htm. Accessed 10 May 2021. 
NORTH, Michael. The Dialect of Modernism: Race, Language, and TwentiethCentury Literature. Oxford UP, 1998.

O’NEILL, Eugene. “The Emperor Jones.” 1920. Early Plays, edited by Jeffrey H. Richards, Penguin Group, 2001, pp. 265-292.

OTERO GARABÍS, Juan. "Esquinas y/o Encrucijadas: Una Mirada al Caribe Urbano en Música y Literatura." Revista Iberoamericana, vol. 75, no. 229, October-December, 2009, pp. 963-981.

PFISTER, Joel. Staging Depth: Eugene O'Neill and the Politics of Psychological Discourse. U of North Carolina P, 1995.

ROHLINGER, Deana A., et al. "Constricting Boundaries: Collective Identity in the Tea Party Movement." Border Politics: Social Movements, Collective Identities, and Globalization, edited by Nancy A. Naples and Jennifer Bickham Mendez, New York UP, 2015, pp. 177-205.

ROSHNAVAND, Farshid Nowrouzi. "Demystification of the Harlem Renaissance. A Critical Analysis of The Primitivist Representational Strategy of the Movement." Sarjana, vol. 28, no. 1, June, 2013, pp. 37-50.

SAIZ, Peter R. "The Colonial Story in 'The Emperor Jones'." The Eugene O’Neill Review, vol. 17, no. 1/2, Spring/Fall, 1993, pp. 30-38.

SAXTON, Alexander. "Blackface Minstrelsy and Jacksonian Ideology." American Quarterly, vol. 27, 1975, pp. 3-28.

SHAKESPEARE, William. Macbeth. 1623. Oxford UP, 2009.

---. The Tempest. 1623. Oxford UP, 2008.

SHIVA, Vandana. "Homeless in the 'Global Village'." Ecofeminism, edited by Maria Mies and Vandana Shiva, Zed Books, 2014, pp. 98-107.

SMITH, Susan H. "The Emperor Jones and National Trauma." Modern Drama, vol. 52, no. 1 , Spring 2009, pp. 57-72.

STEEN, Shannon. "Melancholy Bodies: Racial Subjectivity and Whiteness in O'Neill's The Emperor Jones." Theatre Journal, vol. 52, no. 3, Oct. 2000, pp. 339-359. 
STEINBERG, Stephen. The Ethnic Myth: Race, Ethnicity and Class in America. Atheneum, 1981.

TAYLOR, Verta and Nancy Whittier. "Collective Identity and Lesbian Feminist Mobilization." Frontiers of Social Movement Theory, edited by Aldon Morris and Carol Mueller, Yale UP, 1992, pp. 104-130.

WHITMAN, Robert F. "O'Neill's Search for a "Language of the Theatre" O'Neill: A Collection of Critical Essays, edited by John Gassner, Prentice-Hall, 1964, pp. 142-164.

ZHANG, Wenqian. "Representation of Trauma in The Emperor Jones." Studies in Literature and Language, vol. 8, no. 3, 2014, pp. 116-121. 